\title{
DIFFERENTIATION BASED ON GENDER IN IRANIAN FOOD CULTURE
}

\author{
Gürcan Şevket Avcıoğlu ${ }^{1^{\star}}$ and Gamze Gizem Avcıoğlu² \\ ${ }^{1}$ Dr. Selçuk University, Turkey, gsavcioglu@selcuk.edu.tr \\ ${ }^{2}$ Res. Asst., Selçuk University, Turkey, gizemertan28@hotmail.com \\ ${ }^{*}$ Corresponding author
}

\begin{abstract}
The purpose of this study is to reveal how gender differentiation in the food preparation and consumption behaviors crystallizes in Iran. To this end, observations were made in Tehran, the capital city of Iran, for a period of one month in 2014. Apart from the observations, in order to be able to determine gender differentiations and gender roles in regard to food preparation and consumption, interviews were also held with ten people from different jobs, genders and ages using a semi-structured interview form. As a result of the observations and interviews, it can be stated that modernizations has taken place especially in regard to eating out. However, it was found that traditional gender patterns and gender roles continue with regard to food preparation and consumption at home. In short, the food is seen as a woman's thing.
\end{abstract}

Keywords: Iran, gender, gender roles, food culture

\section{INTRODUCTION}

Society is an organization. People form unions due to goals and needs which they cannot deal with on their own. Variables such as age, gender, profession and interests are influential in the organization of societies into unions. Most of the social unions involve cooperation based on gender. Women and men take part in these unions through both their biological and social characteristics.

It is possible to regard the "female and male genders as both biological and social categories" (Çelebi, 1990, p. 4) due to the differences in their biological and social characteristics. Differentiation between the genders begins with this categorization. However, one should regard the differences as one gender's supremacy over the other because abilities such as intelligence or social skills which both genders possess inherently enable them to fulfill different roles in social unions (Çelebi, 1990, p. 5).

Cooperation and division of labor on the basis of gender can be seen all societies. In other words, genderbased tasks and obligations are encountered in hunter-gatherer, agrarian and industrial societies. While the tasks women and men assume are shared in some societies, genders may at the same time fulfill some of the tasks assumed by the opposite gender. This does not negatively affect the social position of the person 
doing the opposite sex's job. However, in some societies, the tasks to be done by men and women are separated from each other in a clear-cut way. Tasks are divided into men's tasks and women's tasks. The tasks men have to do are generally tasks that are outside of their living spaces and concern the security of the society. Women, on the other hand, are responsible for tasks such as growing foodstuff and taking care of children, which help maintain life (Haviland, 2002, p. 345). Differentiation based on division of labor between the sexes is regarded as a social phenomenon. In reality, this phenomenon is explained through approaches that are related to how the society has been set up. A society is based on differences. One of these differences is gender difference. The reason behind the differentiation both in society and between the genders is usually indicated as a desire to have power. Who will have the power and what the sources of power will be are determined by social processes. Eriksen (2012, p. 201) expresses the establishment of the society on the basis of power as follows "There are differences among people in terms of power in all societies. In this respect, there is no society where everyone in society has the same influence. Social differentiation and inequality are universal phenomena". A categorical differentiation made between the genders may lead to inequality and discrimination in social relationships. Interrelated social relationships help determine the social positions of men and women. Preparing, serving and consuming is one of the social relationships. The categorical differentiation between men and women is also manifest in this form of relationship. Gender differentiation and gender roles are quite distinct in regard to food, which is one of the basic needs of societies.

Food culture or cuisine also demonstrates division of labor and standards of status based on age, gender and class. Nutritional habits are affected by these variables. A society continues ways of eating through acculturation in accordance with these variables. For example, there is a role differentiation between the genders in terms of food preparation and consumption. In Malinowski's (1992) functionalist approach, tools, people and organizations that are used to implement production activities are each a functional component in society. Moreover, division of labor performed by the genders for food production and consumption expresses functional operation of the pieces that constitute the social whole. Thus, the purpose of this study is to investigate how gender differentiation and gender roles in food preparation and consumption behaviors in Iran crystallize. Moreover, although food culture involves various different behaviors and networks of social relationships, this study has been limited to gender-based relationships.

\section{A SHORT EVALUATION ON LITERATURE OF GENDER AND WOMEN'S STUDIES}

Literature is very wide about gender and women, position of women in society, social roles and issues of women, so collecting studies of gender and women is very difficult. Because in society social areas are very variety and women have a position in every social area. Even so, if a literature study is done about studies of gender and women, certain social areas and various concepts can be categoried. For example, Pilcher and Whelehan (2004) explained fifty concepts that is source of gender studies. Besides, about position and status of women in business life (Alonso-Almeida et al., 2015; Sotiropoulou, 2014; Belwal et al., 2014; Khosrokhavar and Ghaneirad, 2010), about houseworks and domestic roles of women (Shirazi, 2005; Jackson, 1992; Fürst, 1997), about women in other social areas apart from home (Elliott, 2014; Shahrokni, 2014) and about women and the representation of women in the media (Oxman-Martinez et al., 2009; Graham and Rich 2014) studies are intensive but the aim of our study isn't to collect literature about gender and women.

\section{GENDER-BASED DIVISION OF LABOR AND DIFFERENTIATION REGARDING FOOD}

It is generally acknowledged in the literatures of sociology and anthropology that the basis of gender differentiation is the society. Genders are determined by the society. Gender indicates how the society interprets gender and how it builds gender identity. The society determines genders as a combination of various factors. Different factors such as class, ethnic relations, racial characteristics, religion, education and economic power are effective in the way a society builds its understanding of gender (Shahidian, 2002a, p. 4).

Anthony Giddens (2000, pp. 96-103) discusses two important factors in the formation of gender. These are innate biological traits and gender identities conveyed by the society. Biological traits affect individuals' sexual attitudes and behaviors. However, what is more influential in the adoption of gender identity is social learning. Different gender features, attitudes and behaviors are conveyed to the child during the learning process. This conveying helps the child understand the differences between the genders and causes the child to apply them in their own relationships. What crystallizes gender differences are, in addition to parents' approaches, materials like children's books which are used in child rearing and the media. In fact, all agents of socialization in society tend to raise the girl as a girl and the boy as a boy. 
As a result of the social learning process, gender roles emerge. Women and men have many gender roles that complement each other. Domestic or familial roles are regarded as the most important one among women's gender roles.

The fact that even if they work outside the home, women perceive working as a contribution to the family budget and believe that they fulfill their roles within the family (Çelebi, 1990, p. 10) is an attitude in support of this. The underlying reason here is the belief that tasks outside the home has to be done by men strictly; for example, working as a manager in a restaurant is seen as a men's job. Restaurant owners prefer to employ male managers and the reason for this is that the other employees in the restaurant refuse to accept a female authority (Moghadam, 2011, p. 54). Gender roles become differentiated clearly in the home as outside the home. The most important roles of the woman in the home are considered to be hygiene and orderliness of the house, taking care of children and cooking. In some discussions, gender differentiation in food preparation and consumption is based on the power struggle between men and women.

It is observed in studies concerning division of labor that while women assume the task of food preparation, men assume the role of bringing home food. Cases where both genders have equal share in regard to food preparation are less frequent (Beardsworth and Keil, 2011, p. 138). In traditional social structures, there is a positive view towards women's doing shopping for food, preparing and serving food and men's eating more frequently and more in amount and consume food that is rich in protein content. In addition, these are regarded as a role that women have to fulfill and a form of consumption appropriate for women. This perception can also be seen in modern societies. However, such a gender differentiation in food preparation and consumption is considered to be to the detriment of women and therefore criticized (Beardsworth and Keil, 2011, pp. 132-135). The idea that different genders eat different food seems to have taken hold among the fixed ideas of societies. Male body is seen as a symbol of power; it is big and powerful. Therefore, man has to eat and drink a lot. By contrast, bodies of children and women are delicate, so they have to eat less and consume light food. This differentiation is reflected in both the language and practices of the two genders (Bourdieu, 2013, p. 35). The reason why power relations are mentioned via food may be that "survival, reproduction or extinction of a species depends on its finding food" (Gisbert, 1973, p. 443).

A result caused by power relations between men and women may sometimes be in the form of violence. There are numerous findings indicating that in some families, women's failure to fulfill the demands of their spouses with regard to their domestic tasks lead to violence against women (Beardsworth and Keil, 2011, p. 144). Food may be one of the reasons for violence. The fact that the woman does not cook adequate amount of food in a meal, or the food is hotter or colder than the man wants or the woman cooks dishes that the man does not like may lead to violence.

Feminist criticism in this regard is based on two fundamental concepts. The first concerns subjection/subordination. Since women are seen to be subordinated to men, they are expected to obey. Women's tasks and obligations regarding food reinforces subordination. The second concerns socialization. The fact that societies regard the task of nutrition as a role to be fulfilled by women is included in the content of the concept of womanhood. Womanhood is taught through the process of socialization (Beardsworth and Keil, 2011, p. 147). In the traditional extended family structure, the woman is subordinated to the man in line with the roles in marriage. However, this does not mean that in modern nucleus family, there is definitely a sharing of the marital roles in favor of equality because even in studies conducted in the United States of America, one can encounter results indicating that marital roles are not perceived as being equal (Çelebi, 1990 , p. 15). One factor that may upset equality between the genders and sometimes may lead to violence concerns financial means. "The fact that man gives the woman money every morning to meet the daily needs is important in that it reminds one of the power differentiation within the family. This strengthens the gender relations already set between the man and the woman (Shahidian, 2002a, p. 6). Establishment of gender relations in a way that favors the superiority of one gender may lead to setting up superiority over the other gender through violence.

Counihan (2005, pp. 1-2), too, bases the relations among food, gender and power on a socio-cultural ground. This relationship is has two aspects. The society determines how man and woman keep food under control and they reach food through a culture which itself has generated. The man of the woman's being able to produce, distribute or consume food reveals their social power. Who can produce or consume food varies by the culture, class structure and family type of a society and this link between the food and gender reveals the power relations within each organization. The second aspect of the relationship concerns the concept of ego. In a person's relationship with their food and body, one can see either approving of or refusing their ego. This is taken to be a reflection of the person's own power.

The following can be said regarding Counihan's distinction made between the society and personality on the 
basis of food, gender and power relations; in the relationship among food, gender and power, the society's determining who can produce and consume food, which is a basic need of men and women determines all the social relationships of that society. For example, matriarchy or patriarchy in some societies takes shape depending on who holds means of food production. In cases where the nutritional needs of a society are met by women, the overall characteristic of that society is one of matriarchy. As far as the issue of ego is concerned, if a person can feed themselves adequately, in other words neither too much nor too little, then they can establish power relations with others through their body. This may give rise to both a physical and a psychological superiority. This is of course related to the perception of body in that society. In a society where physical strength is an important value, a well-fed male body is an indication of strength. Or, in a culture where women are defined through delicacy and elegance, if a woman eats little and thus keeps herself physically thin, then this will increase that woman's social power and status.

Another important issue regarding food in the discussion about the woman's gender roles is the issue of consumption. There is an unending debate regarding women's sensitivity to shopping. Female consumers are severely criticized, claiming that they are extremely affected by marketing and advertising and women are traditionally regarded as consumers (Coleman, 2012, p. 7; Stevens and Maclaran, 2012, pp. 65-67). In fact, women's consumerism is identified with commodity fetishism and modern food culture is considered to be one of these fetishes (Ashley et al., 2004, pp. 100-101). The media turns food, food ingredients and shopping for food into a fetishism. As a matter of fact, this fetishism turned its face to female body and now dieting and vegetarianism have become a part of the food culture of the modern society. The claim that advertisements have directed female consumers to fetishism concerning food can be seen as an exaggerated allegation but such views are being argued and discussed. We can argue that among the gender roles of women, shopping for the family members is passed down as an obligation of women in the process of acculturation so it is natural that they are seen as consumers.

Society and media base gender definition and gender roles on the basis of food. Gender roles are associated, in the form of a competition, with being the best mother, the best spouse and meeting the nutritional needs of the family members (Douglas, 2003, p. 6). Gender differentiation with regard to eating can be expressed briefly in this way.

\section{GENDER DIFFERENTIATION IN IRAN}

Issues like categorization of genders, gender differentiation in social organizations, resulting of this differentiation in inequality and elimination of inequality are universal issues that concern all societies. No society, be it in the West, in Africa or in Asia, is far from debates about gender and inequality. Processes of social change which each society experiences also involve the topic of gender. Changes concerning more equal division of labor are as important for Iran as for Turkey. In all societies, "women problem develops like a debate between traditionalists and proponents of change. However, neither traditions can be preserved, nor changes occur in the manner as they are expected" (Amin, 2002, p. 16).

Education is considered to be an important transformative factor ensuring equality of men and women. It is generally accepted that education of men and women helps develop gender relations outside of the conventional gender patterns and improves an egalitarian attitude between men and women. However, in some cases, different meanings are attached to education. The education that women receive serves to reinforce their subordination to men or better be able to fulfill their domestic roles. An educated woman "can better assist in all of her husband's work, thereby pleasing her man" (Amin, 2002, p. 44) or an educated woman performs home management more efficiently and raises her children in a more informed way. Better performing her womanhood role thanks to education means she is a better spouse. In this approach, education is not for the woman herself but for gender roles.

In a sense, changes in the position of women in society are associated with economic developments. In this regard, Hooglund (2011, p. 121) describes some observations in rural areas of Shiraz follows: In Shiraz, the incomes, lifestyles and values of middle-income families resemble one another's. Young women in these families are enthusiastic about working or continuing their education even after they get married. By contrast, young girls of lower-income families living in the same villages do not much desire to continue their education after high school or work in paid job. Instead, they may prefer to marry a good husband.

A study conducted by Moghadam (2011, pp. 55-56) in Iran indicates that women who can get financial support from their families tend to attend higher education after high school because university education enables them to get better-paid jobs usually done by men and raise their social status. This tendency on the part of women affects their consciousness regarding womanhood and their views concerning marriage and gender relations. For example, education raises the age of marriage and changes the expectations of both sexes from marriage. 
The improvement in the social status of women in Iran took place as a result of various socio-political, socioeconomic and cultural developments and women's movements (Shahidian, 2002b; Amin, 2002). In different periods in Iran, women's roles outside the home increased and effects of women were observed on production, education and political activities (Shahidian, 2002a). Though not very comprehensive, "the rise in the education of women in Iran and their starting to work in public institutions and in economy has weakened men's absolute authority at home" (Shahidian, 2002a, p. 22). Economic developments require women to participate in production as workforce and this participation enables women to take part in social life. Women in Iran not only get involved in economic production but also in social movements aimed at getting their political and gender rights. It has been observed recently that physical attacks on women have been protested widely by women again through street demonstrations. Another factor that enables women to get involved in social life is the media. As in all societies, in Iran, too, the media generally uses women in their roles as mother or spouse but women have a significant representation in means of communication. Women are represented in the fields of politics, production-consumption and thought.

To what extent do social changes in Iran and changes in the way gender roles are perceived get reflected in social life and social relationships? To what extent do the changes that take place when one gets education and begins to work determine the change in gender roles that are passed down through conventional means? Undoubtedly, studies are being conducted in all fields of society to be able to answer these questions. This study, which we carried out in regard to food preparation and consumption, provides a limited image of the gender differentiation in Iran's food culture.

\section{METHOD}

\subsection{The Research Method and Data Collection Instruments}

This study was implemented using the qualitative research design. In the qualitative research design, standard techniques of quantitative studies are used less, the research design belongs to the researcher and, instead of following certain steps, interaction of research techniques is ensured (Maxwell, 2013, p. 3). The observation technique was used in this study. This observation was performed in Tehran, the capital city of Iran, occasionally accompanied by conversations with local people. However, a semi-structured interview form was used to reach findings that could not be obtained through observation. Literature about food was of great assistance in the preparation of the interview questions. The topics discussed in the relevant literature served as a source for the questions.

The interviews were held with 10 Iranian citizens composed of different ages, genders and professions, namely academics, civil servants and housewives. The interviewees were selected using the snowball sampling technique. The snowball sampling technique is one of the non-probability sampling techniques and sometimes considered to be a form of the random sampling technique. After interviews are held with a few people from the group, other people that will be recommended by them to give their ideas about the topic are reached (Babbie, 2014, p. 188). In this study, a group or an event was not investigated. However, since the population and the sample of the study could not be determined through other sampling techniques, interviews were held with a few people first and the other interviewees were chosen upon recommendation by the initial interviewees. Responses given to questions under each title by different people were retold as they were by abbreviating the name and surname of the person responding. Due to the research design, data analysis was not conducted statistically. Only, the responses given to the questions were interpreted.

\subsection{Observations in Tehran}

Some observations were made in central Tehran, Darband, Tajish, Farmanieh, Sa'adat Abad, Tehran Bazaar (Bazare Bozurg), Shahr-e Rey and Baharestan. There are restaurants in these areas where one can eat out and which have soups and stews on their menus. However, it cannot be said that such restaurants are high in number. On the other hand, fast food restaurants where pizzas, hamburgers or varieties of grilled meat can be consumed were more predominant. Apart from food, snack bar-like small-scale shops where one can consume fruit juice were encountered as frequently as fast food restaurants. In those bars, fruit juices like Abutalebi are freshly processed from seasonal fruit and served. It was observed that a large majority of the employees in both restaurants and snack bar-like places were male. Female employees were also encountered in a restaurant near Ferdowsi, in Darband and Farmanieh. There were female cashiers or employees in some restaurants. It was observed that both women and men went shopping to district bazaar and shopping centre.

According to our observations in Tehran, the number of women working in restaurants can be said to be limited. Women usually take part in the invisible part of the food marketing job i.e. in the kitchen. Cooking was entirely undertaken by the lady of the house where we were invited as guests. 


\section{FINDINGS}

During the interviews, how it was prepared, cooked and consumed and whether or not there was division of labor between the sexes in terms of preparing, cooking and consuming were asked.

In both traditional and modern societies, women ensure the continuity of their social status through their functions of culinary work, food preparation and shopping for food. However, this situation "leads to the debate that challenges surrounding food preparation and patterns of consumption serve a function in the family to the detriment of women" (Beardsworth and Keil, 2011, pp. 133-146). Such debates are conducted through the topic that status determiners for women are limited to housework. Some data were obtained about how the division of labor between the sexes takes place in Iran with regard to food preparation.

Which family member does the shopping for food?

Ahmad T.: The lady of the house does it as she is the housewife.

Ali Ş.: Both man and woman do it.

Behrouz B.: It varies by the city and the village; in big cities, women do it but in small places usually men do it. It is almost always women who do it from street vendors.

Ismail T.: The woman chooses and the man buys it. Men buy chicken and meat. Some women do not think men can do it properly, so they do it.

Homeyra M.: Usually, women do the shopping; it is definitely women who buy vegetables but men can buy meat products.

Marjan F.: Women do it.

Mahdi H.: Men usually do the shopping for food. Both men and women do the shopping in district bazaars. Though very rare, street vendors pass by and women buy foodstuff from them.

Younes A.: Men do the shopping because men work and women do the housework at home. Very rarely do women go shopping.

As can be understood from the responses, there is not a clear-cut difference between the sexes in the obtainment of foodstuff to prepare meals in Iran. Both men and women do the shopping depending on the situation and the environment where they live. It is interesting that there is a rural-urban and meat-vegetable distinction in this regard.

What is the role of men in food preparation at home?

Ahmad T.: Men have no role to play.

Ali Ş.: Both men and women do the job.

Behrouz B.: There are men occasionally who do it but usually it is seen as a women's duty.

Ismail T.: Men buy and bring home and women cook.

Homeyra M.: Men never take part in the cooking business; cooking is regarded solely as women's responsibility.

Marjan F.: More young men provide assistance but old men don't.

Mahdi $\mathrm{H}$.: Very little, next to nothing.

Younes A.: Men do not cook, if women have a lot to do, then they help.

It is seen that women have a bigger role in food preparation in Iran. Men do not get much involved in food preparation. Men in İran avoid taking part in food preparation. Cooking is generally seen as women's thing. Of course, it can be said that division of labor in this respect has increased in recent years. The fact that both male and female members of the family should work and that the perception of family has changed to accept equality among the members is increasing the behavior of division of labor between men and women in regard to food preparation.

Who decides what to cook daily? Do men or children object to the food that has been cooked? Do arguments arise due to reasons such as not liking the meal cooked?

Ahmad T.: Men decide. 
Ali Ş.: Everyday, certain foods are cooked; sometimes man proposes and women cooks and sometimes woman wants and man buys.

Behrouz B.: Women themselves decide; women know what dishes their men love.

Ismail T.: Some women cook whatever they like. Some ask their men. Objections are made and when women disregard, then an argument breaks out. Women dominate.

Marjan F.: Men decide. It depends on how children are brought up; they sometimes do not like the meal cooked. Sometimes arguments break out.

Mahdi $\mathrm{H}$.: Men decide. Arguments do not break out at home because of food because after all women cook the food men like.

Younes A.: Women after all know what men like. Sometimes men say what they want and even if the meal is not liked, a little of it is eaten not to offend the women.

It is possible to say that men can have the final say in what dish to cook though not necessarily in how to cook it. The fact that men decide what dish to cook reveals differentiation in status in the family. Likewise, the fact that women know what their men want and cook accordingly is an indication of men's superiority.

What are the roles of men and women working in food services outside?

Ali Ş.: Women's role is much less; men have a bigger role.

Behrouz B.: Mostly men do the work; women are much fewer in number. Recently, home-made food has begun to be sold. Women do this.

Ismail T.: Women's role is very limited. Those who cook are generally men. There may be very few women working.

Marjan F.: Men are higher in number; there are very few female waitresses. Male cooks are much higher in number.

Mahdi H.: Female cooks are very limited.

Younes A.: Both have roles; men usually work outside the city. Both men and women work in the city. It depends on the place.

Whether women will work outside in the food sector is usually determined by the attitude of the society towards women's working. In many societies, there is a categorization in jobs where women can work and where men can work. Gender discrimination and women's working in lower-status jobs are important problems in working life. As far as food is concerned, there is a general expectation that women should prepare and serve food at home (McIntosh, 1996, pp. 79-80). Although men seem to fill the positions in the food sector in registered economy, much of the food preparation job like shopping and kitchen work is conducted by women (Warde, 1997, p. 22). However, women's working in food industry outside home may be a more fitting job for women, maybe because of their role at home.

Are there any dishes that only men, women, children or the elderly consume or consume more frequently? Does everyone consume the same amount of meat, vegetables and fruit?

Ahmad T.: Everyone eats meat, mixing it (with other foods).

Ali Ş.: Meat is consumed a lot. Both men and women do.

Behrouz B.: More or less, yes there are but everyone eats everything, yet children are not served cola.

Ismail T.: Everyone consumes rice and the like, everything which they can serve with rice on top. Everyone eats meat. Children eat less meat, however. It depends on individuals.

Marjan F.: This is important for some countries but not for us; everyone eats everything.

Masoumeh K.: Everyone consumes everything. Sometimes, some people feed girls more when they are pregnant.

Younes A.: When there is much to do outdoors, foods that give ample energy (mugavvi) are consumed. Children eat less, they eat the same foods as adults but men eat more.

In some cultures, foods with protein and carbohydrate content are predominantly consumed and there is a differentiation in consumption in terms of age, gender and class. Consumption of foods with high protein content does not differ by age and gender in Iran. In other words, foods are not subjected to gender 
discrimination by attributing masculinity and femininity to them. Generally, meat is referred to as male whereas vegetables and fruit are regarded as female and therefore meat is men's food while vegetables and fruit are women's things. However, there is no such differentiation in Iran. This does not mean that a relationship between certain foods and masculinity and femininity is not established.

Is there a difference in food quality and variety in terms of income groups?

Ahmad T.: Of course, there is.

Ali Ş.: There is a difference; the rich eat more meat and turkey whereas the poor eat biscuits or muffins.

Behrouz B.: There is a huge difference.

Ismail T.: Of course, better quality and more varied.

Marjan F.: Of course, there is.

Mahdi $\mathrm{H}$.: Those with high income consume muscle and neck meat as well as special fish and they even once consumed gold dust but it is now forbidden.

Younes A.: Foods do not vary much depending on income groups. It is because lifestyles are similar and dishes are similar; differences were greater in the past.

Although there is no difference in the consumption of food items in the family that families could reach in terms of age or gender, it is understood that income-based class differences are effective in food consumption. That is, consumption of good quality foods and meat does not vary among mothers, fathers and children, groups with high and low incomes are distinguished from each other in this respect. This income inequality exists in all societies and is reflected in food consumption habits.

How much convenience (or frozen) food is consumed at home? Is there a deep freezer in every home?

Ali Ş.: Frozen foods, lentils and sabzi ghormeh are put in a deep freezer. There is a deep freezer in almost every home.

Homeyra M.: Foods may be kept in deep freezers. But, convenience foods are not consumed at home; dishes at home are made from fresh vegetables.

Masoumeh K.: We use deep freezers to consume vegetables out of season. Housewives do not prefer to use convenience foods. Only working women do.

Soheila M.: Convenience foods are bought as they are convenient for working women but not much. Mostly fresh produce is preferred.

Consumption of convenience foods at home is a situation depending on working conditions. Convenience foods are not much preferred in families where women do not work. As in Iran, freezers are frequently used at home to store vegetables to be consumed out of season and to preserve meat products.

Are family members expected to come together at dinners?

Ahmad T.: They usually eat together; they wait for the father to come.

Ali Ş.: They don't in Tehran but they do in villages. There is no time in Tehran and there is too much traffic.

Behrouz B.: This tradition is about to be broken; families did not use to start the meal before the father came home.

Ismail T.: Usually, family members are expected to come together.

Marjan F.: The family is expected to come together. This depends on the family. Each eats the meal upon coming home.

Mahdi $\mathrm{H}$.: All family members are expected to arrive, in some families, even if one family member is missing, the table is not laid.

Younes A.: They come together.

The coming-together of the family at dinner table is a tradition that is wanted to be kept in many societies for the sake of family unity. In some communities, the superior position of the father as the family elder is maintained at dinner table. Also, it is becoming hard for the family members to come together at especially the dinner table due to the hard working conditions. 


\section{CONCLUSION}

According to the findings obtained from the observations and interviews, there are differences between genders in Iran in terms of food preparation, shopping and cooking are regarded as women's thing.

Obtainment of food items, i.e. shopping for food, has not been entirely left to women. Men are seen to interfere in the task of buying foodstuff. Both women and men can be seen doing shopping in supermarkets and local bazaars. However, it can be argued that there is a general consensus in society that shopping for food is a women's task.

Men have almost no role in preparing food at home. Rarely do men take part in preparing food at home.

Deciding what dishes to cook seem to depend on men's wish because women's knowing what dishes their husbands like and cooking them reduce or eliminate the arguments that may arise due to food.

It is seen that when it comes to preparing and serving food outside the home, men have more role than women. This indicates that food-related roles attached to women are limited to the home only.

It is observed that unlike some cultures, there are no differences among women, men and children in regard to the content of the food eaten, i.e. the consumption of dishes containing protein, carbohydrates and vitamins. Although no gender and age differences are observed concerning the content of the foods consumed, it can be argued that there are differences among income groups.

The fact that generally waits for the father to come home in order to convene at dinner table and the order of seating at the dinner table indicates that the traditional father figure maintains its influence on eating behaviors.

Although the increase in women's education, income and participation in working life has an effect on social relations in Iran and reorganizes and modernizes women's and men's relationships in daily life, it can be argued that traditional gender patterns seem to persist in food preparation and consumption and eating behaviors. It is seen that gender differentiation and gender roles in food preparation and consumption are distinct. In short, cooking seems to be a women's job.

\section{REFERENCE LIST}

Alonso-Almeida M. del Mar, Perramon, J. and Bagur, L. (2015). Women managers and corporate social responsibility (CSR) in Spain: perceptions and drivers. Women's Studies International Forum, Vol. 50, pp. 47-56.

Amin, C. M. (2002). The making of the modern Iranian women: gender, state policy and popular culture. 1865-1946. Gainesville: University Press of Florida.

Ashley, B., Hollows, J., Jones, S. and Taylor, B. (2004). Food and cultural studies. London: Routledge.

Babbie, E. (2014). The practice of social research (14 ${ }^{\text {th }}$ edition). Boston: Cengage Learning.

Beardsworth, A. and Keil, T. (2011). Yemek sosyolojisi, yemek ve toplum çalışmalarına bir davet. Transl. A. Dede, Ankara: Phoenix Yayınevi.

Belwal S., Belwal R., Saidi F. Al (2014). Characteristics, motivations, and challenges of women entrepreneurs in Oman's Al-Dhahira Region. Journal of Middle East Women's Studies, Vol. 10, Nr. 2, Spring, pp. 135-151.

Bourdieu, P. (2013). Distinction: a social critique of the judgement of taste. Trans. R. Nice, In Food and Culture: a reader, edited by C. Counihan and P. V. Esrerik, New York: Routledge, pp. 31-39.

Coleman, C. A. (2012). Construction of consumer vulnerability by gender and ethics of empowerment. In Gender, Culture and Consumer Behavior, edited by C. C. Otnes and L. T. Zayer, New York: Routledge, pp. 3-32.

Counihan, C. M. (2005). Food and gender: identity and power. In Food and Gender: Identity and Power, edited by C. M. Counihan and S. L. Kaplan, Taylor \& Francis e-Library, http://elibrary.kiu.ac.ug:8080/jspui/bitstream/1/853/1/Food\%20and\%20Gender\%20ldentity\%20and\%2 OPower.pdf, pp. 1-11.

Çelebi, N. (1990). Kadınlarımızın cinsiyet rolü tutumları. Konya: Sebat. 
Douglas, M. (2003). Standart social uses of food: introduction. In Food in the Social Order, Oxon: Routledge, pp. 1-39.

Elliott, K. Z. (2014). Morocco and its women's rights struggle: a failure to live up to its progressive image. Journal of Middle East Women's Studies, Vol. 10, Nr. 2, Spring, pp. 1-30.

Eriksen, T. H. (2012). Küçük yerler, büyük meseleler sosyal ve kültürel antropoloji. Trans. A. E. Koca, Ankara: Birleşik.

Fürst, E. L. (1997). Cooking and femininity. Women's Studies International Forum, Vol. 20, Issue 3, pp. 441449.

Giddens, A. (2000). Sosyoloji. Trans. H. Özel and C. Güzel, Ankara: Ayraç.

Gisbert, P. (1973). Fundementals of Sociology. Kolkata: Orient Longman Private Limited.

Graham, M. and Rich, S. (2014). Representations of childless women in the Australian print media. Feminist Media Studies, Vol. 14, Issue 3, pp. 500-518.

Haviland, V. A. (2002). Kültürel Antropoloji. Trans. H. İnanç and S. Çiftçi, İstanbul: Kaknüs.

Hooglund, E. (2011). Changing attitudes among women in rural Iran. In Gender in Contemporary Iran, edited by R. Bahramitash and E. Hooglund, Oxon: Routledge, pp. 120-135.

Jackson, S. (1992). Towards a historical sociology of housework: a materialist feminist analysis. Women's Studies International Forum, Vol. 15, Issue 2, pp. 153-172.

Khosrokhavar, F. and Ghaneirad M. A. (2010). Iranian women's participation in the academic world. Iranian Studies, 43: 2, pp. 223-238.

Malinowski, B. (1992). Bilimsel bir kültür teorisi. Transl. S. Özkal, İstanbul: Kabalcı Yayınları.

Maxwell, J. A. (2013). Qualitative research design: an interactive approach (3 ${ }^{\text {rd }}$ edition). Thousand Oaks CA: Sage Publications.

Mclntosh, W. A. (1996). Sociologies of food and nutrition. New York: Plenum Press.

Moghadam, F. E. (2011). Women and social protest in the Islamic Republic of Iran. In Gender in Contemporary Iran, edited by R. Bahramitash and E. Hooglund, Oxon: Routledge, pp. 36-44.

Oxman-Martinez, J., Marinescu, V. and Bohard, I. (2009). Shades of violence: the media role. Women's Studies International Forum, Vol. 32, Issue 4, pp. 296-304.

Pilcher, J. and Whelehan, I. (2004). 50 key concepts in gender studies. London: Sage Publications Ltd.

Shahidian, H. (2002a). Women in Iran: gender politics in the Islamic Republic. Westport: Greenwood Press.

Shahidian, H. (2002b). Women in Iran: emerging voices in the women's movement. Westport: Greenwood Press.

Shahrokni, N. (2014). The mother's paradise: women-only parks and the dynamics of state power in the Islamic Republic of Iran. Journal of Middle East Women's Studies, Vol. 10, Nr. 3, Fall, pp. 87-108.

Shirazi, F. (2005). The sofreh: comfort and community among women in Iran. Iranian Studies, 38: 2, pp. 293309.

Sotiropoulou, I. (2014). Women in alternative economy or, what do women do without official currency? Women's Studies International Forum, Vol. 47, Part B, pp. 339-348.

Stevens, L. and Maclaran, P. (2012). The carnal feminine: consuming representations of womanhood in a contemporary media text. In Gender Culture and Consumer Behavior, edited by. C. C. Otnes and L. T. Zayer, New York: Routledge, pp. 63-86.

Warde, A. (1997). Consumption food and taste. London: Sage Publications Ltd. 